\title{
CONSUMPTION BEHAVIOR OF BIDIKMISI SCHOLARSHIP STUDENTS WITH RELIGIOSITY AS A MODERATING VARIABLE
}

\author{
Muhammad Yafiz a \\ Isnaini Harahap b \\ Sri Cahyanti ${ }^{\mathrm{c}}$ \\ ${ }^{a, b}$ Faculty of Economics and Business Islamic State University of North Sumatera \\ 'Postgraduate Masters, Islamic State University ofNorth Sumatera \\ Email:muhammadyafiz@uinsu.ac.id ${ }^{a}$; isnaini.harahap@uinsu.ac.id ${ }^{b}$, sricahyanti88@gmail.com
}

ARTICLE HISTORY

Received:

19 September 2020

Revised:

3 November 2020

Accepted:

18 November 2020

Online available:

11 December 2020

Keywords:

Consumption Behavior,

Income,

Lifestyle,

Religiosity,

Social Environment.

*Correspondence:

Name: Sri Cahyati

E-mail:

sricahyanti88@gmail.com ${ }^{c}$
ABSTRACT

A person's consumption depends on the amount of income earned. If a person's income increases, then consumption will also increase. Conversely, if income decreases, then consumption will also decrease. This study aims to analyze the influence of income, lifestyle, and social environment variables on student consumption behavior with religiosity as a moderating variable. The research method used is a quantitative method using anaccidental sampling technique. The data analysis technique applied is the Moderated Regression Analysis (MRA) test of SPSS 19.0. The results show that income has a positive and significant effect on student consumption behavior by $29.8 \%$, lifestyle has a positive and significant impact on student consumption behavior by $27.6 \%$, and social environment has a positive and significant effect on student consumption behavior by $24.1 \%$. Income, lifestyle, and social environment simultaneously have a positive and significant impact on student consumption behavior with a significance value obtained reaches $0.000<0.05$, and Fcount is greater than Ftable (26.398> 2.47). Religiosity has a significant impact on consumption behavior with a significance value obtained of $0.036<0.05$, and tcount is greater than ttable (2.123> 1.985). Religiosity does not strengthen income, lifestyle, and social environment against consumption behavior. Income, lifestyle, and social environment have a positive effect on student consumption behavior with a moderate level of religiosity. In addition, religiosity affects consumption behavior, therefore it can be concluded that religious knowledge or ideology can influence consumers in choosing goods to consume, based on the value they believe in. 


\section{INTRODUCTION}

One of the government policies to overcome the problem of expensive tuition fees is to free education fees or provide free education through scholarship programs. This policy is expected to support students with low economic backgrounds but excel in tertiary institutions, and this program aims to improve their achievement. Education Costs for Poor and Achieving Students (Bahasa: Bidikmisi) scholarship is a financial aid for education and living expenses given to prospective students who are economically disadvantaged with academic potential. The government offers this scholarship through the Directorate General of Higher Education (Bahasa: Dirjen Dikti) of the Ministry of Education and Culture starting in 2010 (Universitas Islam Negeri Sumatera Utara, 2015).The Bidikmisi scholarship is aimed to create human resources capable to contribute in breaking the chain of poverty and community empowerment.

The financial aid provided in the Bidikmisi program comprises living expenses of IDR 700,000 per month and the cost of administering education managed by higher education institutions of IDR 2,400,000 per semester for each student. The student living expenses fund (IDR 4,200,000 per semester) is interesting to discuss since each student is potentially use it for different needs with different amounts (Universitas Islam Negeri Sumatera Utara, 2015). This difference will not be a problem if it remains following the objectives of the Bidikmisi scholarship. The objective's accomplishment depends on the fund utilization of its recipients, whether they benefit the scholarships according to their goals or not. The scholarship's purpose will be achieved if they can properly utilize its fund (Arifin et al., 2013). If the students possess a good financial literacy, they will manage finance wisely to avoid over excessive or highly consumptive behavior (Ardyanti, 2018).

Based on the interview results with Bidikmisi scholarship managers, reports on the fund utilization of students in each semester indicate that they have not been benefited from it to the uttermost. The government provides scholarships whose initial function is to support student educational process and increase their academic achievement. They have misused to finance their needs apart from academic field education, for example, purchasing clothes, shoes, bags, and other accessories, even using the scholarship fund to purchase cellular phones for their personal needs. Furthermore, based on the author's observations while interacting with the Bidikmisi scholarship awardees at the State Islamic University of North Sumatra, Medan, it is found that some of them are more fashionable and attractive than usual students, especially among female ones. This condition shows the uniqueness of Bidikmisi students, for example, students who should shop for books to support their education, they turn to focus more on shopping related to their appearance. It will lead to the consumptive behavior among Bidikmisi students. Because of their

Published by University of Airlangga.

This is an open access article under the CC BY license (https://creativecommons.org/licenses/by-nc-sa/4.0/) 
consumptive nature, the use of scholarship fund is prone to be used for ineffective consumption since they no longer practice the priority scale of needs.

Consumer behavior is a behavior shown by consumers in finding, buying, using, evaluating, and spending the products and services they expect to satisfy their daily needs (Sheldon, 2014). In terms of consumer behavior study, one implication is that generalizations of consumer behavior are usually limited to certain periods, products, and specific individuals or groups (Sheldon, 2014). Consumptive behavior is a buying behavior that is no longer based on rational considerations, but because of a desire that has reached an irrational level (Anggraini, 2017). The human tendency towards consumptive lifestyles outside of basic needs is prohibited in Islam, as explained in QS. Al-A'raf (7): 31, with the meaning: "Children of Adam! Wear your nice clothes at every (enter) mosque, eat and drink, but do not overdo it. Indeed, Allah does not like extravagant people."

The verse above explains that people should not exceed the limits needed by the body and halal foods. According to Baining \& Ekawati (2018), excessive consumption is a characteristic of people who do not know God. Islam condemns such behavior referring to as Israaf (extravagance) or Tabziir (squandering property without use). Tabziir means using property in the wrong way. Waste means excessive use of the property for things that violate the law, such as food, clothing, and shelter. Islam advocates a fair and balanced pattern of consumption and property use, namely a practice that lies between stinginess and waste (Baining, 2018). Consumption in Islam must be oriented towards benefits, namely beneficial both materially, physically, intellectually, environmentally, and of course, in the long term. Islam, as one religion revealed by Allah SWT, has regulated all human affairs on this earth, one of those is consumption. A devout Muslim consumer, he will realize that he should spend his property on individual needs and the way of Allah SWT. A Muslim who is wise should be able to practice the knowledge he has in his daily life as a form of a servant's obedience to Allah SWT. The ability of the community or someone to practice the teachings of their religion can be seen from the level of compliance or religiosity they possess.

It often identifies religiosity with a way of religion. Religiosity is how far the knowledge is, how strong the belief is, how much the practice of worship and rules is, and how deep the appreciation of the religion one adheres to be. For a Muslim, religiosity can be seen from the extent of knowledge, belief, implementation, and appreciation of Islam. we can define religiosity as a condition that exists within an individual that encourages him to behave following his obedience level to religion, dimension of religiosity suppressing the value of materialism, and on the other side increasing subjective wellbeing simultaneously (Lutfia, 2020). Therefore, religiosity is considered representing how a Muslim can implement what he believes and understands from the teachings of his belief in everyday life, including in consumption activities. Consumption cannot be separated 
from the role of faith, where it is essential as a benchmark since faith provides a perspective on living life that tends to affect human personality. Faith offers a moral filter in spending assets and utilizing income for what is useful. The moral filter aims to keep oneself within the boundaries of social interests with harmonious actions between individuals and social life, and includes filters to create goodness and benefits that can affect consumer perceptions.

Several factors lead to consumptive behavior mostly found in students. One of the economic factors is income. A person's consumption depends on the amount of income earned (Hidayati, 2020). If a person's income increases, consumption will also increase. if income decreases, consumption will also decrease. Each person's consumption can vary according to needs and income levels. A different amount of income is a significant determinant of consumption. Even for some people who have the same income, their consumption can be different (Baining, 2018). The income level to the consumption level has a close relationship, as income and wealth are the main determining factors in consumption (Indrianawati, 2017). Lifestyle is a way of life that indicates how people spend their time (activities), what they consider important in their environment (interests), and what they think about themselves and also the world around them (opinions) (Haryani, 2015). The lifestyle of society will differ from other cultures. Even from time to time, the lifestyle of a particular individual and community group will move dynamically. However, the lifestyle does not change quickly, therefore at a specific time, the lifestyle is relatively permanent. The concept related to lifestyle is psychographics. the social environment is a place where people interact and do something together with each other and their environment. The social environment is one factor that can influence a person or group to act and change the behavior of each individual. Humans are social creatures and cannot live alone. They interact with their families, siblings, friends, and people around them. Therefore, environmental factors play a considerable role in shaping a person's consumptive behavior (Subagio, 2019).

Based on the phenomena mentioned above, consumptive behavior is fascinating to research. In recent days, consumptive behavior is often found in various social life, especially among students who receive Bidikmisi scholarships at the State Islamic University of North Sumatra, Medan. Moreover, with religiosity as a moderating variable.

\section{LITERATURE REVIEW}

\section{The Relationship between Income and Consumption Behavior}

Income has an influence on the amount of one's consumption expenditure. The individual uses his income to buy the things he needs (Rahman, 2020). The bigger the income, the more consumption expenditure will usually increase. A person who has a 
greater income, he has more money to spend on consumption activities. Previous research has proven that income has a positive effect on consumption behavior (Hermanto, 2015). Students with a large income, the more money they can use for shopping (Rakrachakarn, 2015). Thus, income can affect the student's consumption level. Income or pocket money they have can be from parents, scholarships, or jobs they do. The moment a student has a certain amount of income, it often tempts him to spend, assuming that he has some unused income.

\section{The Relationship between Lifestyle and Consumption Behavior}

A person's lifestyle which is illustrated by a tendency to spend without limits and to prioritize the desire rather than the needs is a characteristic of someone with a consumptive lifestyle. They spend on things they really do not need to create maximum pleasure. This happens because of a high desire to own things without considering whether those are needed or not. In addition, they consume without rational consideration or basic needs. For example, buying products to maintain appearance and prestige, or perhaps only a status symbol. They are also willing to pay money only to imitate other people or follow the trend, and they buy expensive products considered providing physical satisfaction and comfort.

From the explanation above, it shows that lifestyle affects consumption behavior (Kanserina et al., 2015;Astuti, 2016). When students have a lifestyle that is consumptive, they behave extravagantly (Khairat, 2018). This can further increase the consumption expenditure. Therefore, the lifestyle that is consumptive can affect the students' consumption level.

\section{Relationship between Social Environment and Consumption Behavior}

The social environment is a container or means of interacting with other people and forming a person and influencing one's behavior. Budanti (2017) and Subagio (2019) in their research state that the social environment has a positive effect on consumptive behavior in students. The social environment has an influence on consumption behavior carried out by individuals. This also indicates that students will behave in a more rational consumption manner if the environment provides examples and role models for disciplined consumption behavior(Sheldon, 2014). Thus, there is a positive influence from the environment which will change the mindset of students in consuming to make it more rational. A good social environment will affect a person's personal or behavior to be good as well. 


\section{Relation of Religiosity to Consumption Behavior}

Religiosity has a religious meaning or is religiously related. Religiosity is the deepening of religion and the practice of religious teachings, especially Islamic teachings, which are used to see whether individuals have studied or practiced their religious teachings so they can influence the behavior in their lives (Fauzi, 2020). Rakrachakarn (2015) explains that religiosity is related to someone's practice regarding religious relations with the conditions that occur in individuals that can make them behave not deviating from the rules of their religion.

Basically, religiosity has a relationship in every aspect of life, including students' consumption behavior. Human behavior and attitudes as social beings are directly influenced by cultural aspects, at least by religion from the environment they live in and the impact to happiness (Sirgy, 2013). Itself is related to their behavior or consumption patterns. The research conducted by Isnaini (2020) states that one's religiosity will influence economic behavior, one of which is consumer behavior. Yustati (2015) and Handa (2013) state that the higher the level of religiosity (religious understanding and its application), the lower the level of consumerism (buying behavior that considers luxury goods as a measure of happiness).

\section{RESEARCH METHOD}

The research is at the State Islamic University of North Sumatra, Medan, Jalan Williem Iskandar Pasar V Medan Estate. The study population includes students who receive bidikmisi scholarships at the State Islamic University of North Sumatra, Medan, batch 2016, 2017, 2018, and 2019. The research population number reaches 949 students. The sampling technique uses simple random sampling and the Solving formula is applied to determine the number of samples obtaining 100 students. This study focuses on primary and secondary data sources. This study's primary data are collected from responses/answers to questionnaire statements following the conditions/situations/feelings experienced directly by the respondents. Furthermore, secondary supporting data are from various literatures, such as journals and relevant books. This study implements Likert scale as an instrument to compile questionnaire data collection with the following scale (Sugiyono, 2017). 
Jurnal Ekonomi dan Bisnis Islam, Vol. 6, No. 2, July - December 2020

Table 1

Likert Scale Instrument

\begin{tabular}{ccc}
\hline Number & Statement & Score \\
\hline $\mathbf{1 .}$ & Strongly agree (SA) & 5 \\
$\mathbf{2}$ & Agree (A) & 4 \\
$\mathbf{3 .}$ & Less Agree (LA) & 3 \\
$\mathbf{4 .}$ & Disagree (D) & 2 \\
$\mathbf{5 .}$ & Totally Disagree (TA) & 1 \\
\hline
\end{tabular}

Source: Processed Data

The analysis method applied is Moderated Regression Analysis (MRA), a special application of linear multiple regression where the equation contains elements of interaction or multiplication of two or more independent variables. The moderate analysis is employed to estimate the value of $Y$ variable based on the value of $X$ variable multiplied by $Z$ variable and to estimate the change in $Y$ variable for each unit difference in $X$ variable multiplied by $Z$ variable. The data processing runs the SPSS 22 software. In this study, there are independent variables, namely income (X1), lifestyle (X2), and social environment (X3); the dependent variable is consumption behavior ( $\mathrm{Y}$ ); and the moderating variableis religiosity $(Z)$. The operational definition of variables in this study is:

\section{a. Consumption Behavior}

Consumer behavior is defined as consumers' behavior in finding, buying, using, evaluating, and spending the products and services they hope to satisfy their daily needs (Suminar, 2015). The indicators measured in consumption behavior are buying products because of the lure of gifts, buying products since the packaging is attractive, buying products to maintain one's appearance and prestige, buying products based on price considerations (instead of benefits or uses), buying products to maintain perspective symbols, wearing products because of conformity to the advertising model, buying products at high prices to increase self-confidence, the desire to try over two similar products with different brands (Haryani, 2015).

b. Religiosity

Religiosity is defined as a condition that exists within an individual that encourages him to behave following the level of his obedience to religion. The dimensions of religiosity in this study are belief (ideological), religious practice (ritualistic), experience (experimental), religious knowledge (intellectual), and practice (consequential).

c. Income

Income is the amount of revenue received by students in a certain period (per month), measured in units of currency (rupiah) from their jobs (Ratna, 2015). The income they earn every month may come from their parents, scholarships, or work measured in units of currency (rupiah). 


\section{d. Lifestyle}

Lifestyle is defined as a way of life identified by how people spend their time (activities), what they consider important in their environment (interests), and what they think about themselves and also the world around them (opinions). Lifestyle in this study is measured by three dimensions of a lifestyle perspective: activities, interests, and students' opinions.

e. Social Environment

Social environment is a place where people interact with each other and do something together with others and their environment to form a person and influence one's behavior. The dimensions of the social environment in this study are reference group, family, and social roles and status.

\section{RESULTS AND ANALYSIS}

\section{Validity Test}

Table 2

Validity Test Results $\mathrm{X}_{1}$

\begin{tabular}{cccc}
\hline Statement & R Count & R Table & Information \\
\hline $\mathbf{1}$ & 0.524 & 0.1654 & Valid \\
$\mathbf{2}$ & 0.463 & 0.1654 & Valid \\
$\mathbf{3}$ & 0.599 & 0.1654 & Valid \\
$\mathbf{4}$ & 0.307 & 0.1654 & Valid \\
$\mathbf{5}$ & 0.481 & 0.1654 & Valid \\
$\mathbf{6}$ & 0.278 & 0.1654 & Valid \\
$\mathbf{7}$ & 0.331 & 0.1654 & Valid \\
$\mathbf{8}$ & 0.345 & 0.1654 & Valid \\
$\mathbf{9}$ & 0.584 & 0.1654 & Valid \\
$\mathbf{1 0}$ & 0.416 & 0.1654 & Valid \\
$\mathbf{1 1}$ & 0.334 & 0.1654 & Valid \\
$\mathbf{1 2}$ & 0.332 & 0.1654 & Valid \\
$\mathbf{1 3}$ & 0.514 & 0.1654 & Valid \\
$\mathbf{1 4}$ & 0.718 & 0.1654 & Valid \\
$\mathbf{1 5}$ & 0.412 & 0.1654 & Valid \\
$\mathbf{1 6}$ & 0.489 & 0.1654 & Valid \\
$\mathbf{1 7}$ & 0.521 & 0.1654 & Valid \\
$\mathbf{1 8}$ & 0.480 & 0.1654 & Valid \\
$\mathbf{1 9}$ & 0.305 & 0.1654 & Valid \\
\hline
\end{tabular}

Source: Processed data 
The validity test results show that all items of the income variable $\left(X_{1}\right)$ are declared valid.

\begin{tabular}{cccc}
\multicolumn{5}{c}{ Table 3 } \\
\cline { 2 - 4 } Validity Test Results $X_{2}$ \\
\hline $\mathbf{1}$ & $\mathbf{R}$ Count & R Table & Information \\
$\mathbf{2}$ & 0.805 & 0.1654 & Valid \\
$\mathbf{3}$ & 0.811 & 0.1654 & Valid \\
$\mathbf{4}$ & 0.819 & 0.1654 & Valid \\
$\mathbf{5}$ & 0.777 & 0.1654 & Valid \\
$\mathbf{6}$ & 0.831 & 0.1654 & Valid \\
$\mathbf{7}$ & 0.800 & 0.1654 & Valid \\
$\mathbf{8}$ & 0.592 & 0.1654 & Valid \\
$\mathbf{9}$ & 0.561 & 0.1654 & Valid \\
$\mathbf{1 0}$ & 0.669 & 0.1654 & Valid \\
$\mathbf{1 1}$ & 0.656 & 0.1654 & Valid \\
\end{tabular}

Source: Processed Data

The validity test results show that all items of the lifestyle variable $\left(\mathrm{X}_{2}\right)$ are declared valid.

\begin{tabular}{cccc}
\multicolumn{5}{c}{ Table 4 } \\
\cline { 2 - 4 } Validity Test Results $X_{3}$ \\
\hline Statement & R Count & R Table & Information \\
\hline $\mathbf{1}$ & 0.681 & 0.1654 & Valid \\
$\mathbf{2}$ & 0.523 & 0.1654 & Valid \\
$\mathbf{3}$ & 0.628 & 0.1654 & Valid \\
$\mathbf{4}$ & 0.618 & 0.1654 & Valid \\
$\mathbf{5}$ & 0.657 & 0.1654 & Valid \\
$\mathbf{6}$ & 0.663 & 0.1654 & Valid \\
$\mathbf{7}$ & 0.648 & 0.1654 & Valid \\
$\mathbf{8}$ & 0.627 & 0.1654 & Valid \\
$\mathbf{9}$ & 0.605 & 0.1654 & Valid \\
$\mathbf{1 0}$ & 0.631 & 0.1654 & Valid \\
\hline
\end{tabular}

Source: Processed Data 
The validity test results show that all items of the social environment variable $\left(\mathrm{X}_{3}\right)$ are declared valid.

Table 5

Validity Test Results Z

\begin{tabular}{|c|c|c|c|}
\hline Statement & R Count & R Table & Information \\
\hline 1 & 0.673 & 0.1654 & Valid \\
\hline 2 & 0.619 & 0.1654 & Valid \\
\hline 3 & 0.669 & 0.1654 & Valid \\
\hline 4 & 0.439 & 0.1654 & Valid \\
\hline 5 & 0.614 & 0.1654 & Valid \\
\hline 6 & 0.709 & 0.1654 & Valid \\
\hline 7 & 0.508 & 0.1654 & Valid \\
\hline 8 & 0.529 & 0.1654 & Valid \\
\hline 9 & 0.622 & 0.1654 & Valid \\
\hline 10 & 0.759 & 0.1654 & Valid \\
\hline 11 & 0.536 & 0.1654 & Valid \\
\hline 12 & 0.547 & 0.1654 & Valid \\
\hline 13 & 0.605 & 0.1654 & Valid \\
\hline 14 & 0.369 & 0.1654 & Valid \\
\hline 15 & 0.634 & 0.1654 & Valid \\
\hline 16 & 0.460 & 0.1654 & Valid \\
\hline 17 & 0.602 & 0.1654 & Valid \\
\hline 18 & 0.689 & 0.1654 & Valid \\
\hline 19 & 0.614 & 0.1654 & Valid \\
\hline 20 & 0.581 & 0.1654 & Valid \\
\hline 21 & 0.656 & 0.1654 & Valid \\
\hline 22 & 0.490 & 0.1654 & Valid \\
\hline 23 & 0.678 & 0.1654 & Valid \\
\hline 24 & 0.633 & 0.1654 & Valid \\
\hline 25 & 0.483 & 0.1654 & Valid \\
\hline 26 & 0.661 & 0.1654 & Valid \\
\hline
\end{tabular}

Source: Processed Data 
The validity test results show that all items of the religiosity variable $(Z)$ are declared valid.

\section{Reliability Test}

Table 6

Reliability Test Results

\begin{tabular}{lccc}
\hline \multicolumn{1}{c}{ Variable } & Cronbach's Alpha & Alpha Coefficient & Information \\
\hline Income & 0.776 & 0,60 & Reliable \\
Lifestyle & 0.912 & 0,60 & Reliable \\
Social Environment & 0.829 & 0,60 & Reliable \\
Consumption Behavior & 0.796 & 0,60 & Reliable \\
Religiosity & 0.920 & 0,60 & Reliable \\
\hline
\end{tabular}

Source: Processed Data

The reliability test results show that all variables are reliable with Cronbach Alpha value greater than 0.60 .

\section{Normality Test}

Table 7

Test Results of Normality Kolmogrov-Smirnov

\begin{tabular}{llr}
\hline & One-Sample Kolmogorov-Smirnov Test \\
& & Unstandardized Residual \\
\hline $\mathrm{N}$ & Mean & 100 \\
Normal Parameters ${ }^{\mathrm{a}, \mathrm{b}}$ & Std. Deviation & .0000000 \\
Most Extreme Differences & Absolute & 7.80367583 \\
& Positive & .057 \\
& Negative & .044 \\
Test Statistic & & -.057 \\
Asymp. Sig. (2-tailed) & & .057 \\
a. Test distribution is Normal. & $.200^{c, d}$ \\
b. Calculated from data. & \\
c. Lilliefors Significance Correction. & \\
d. This is a lower bound of the true significance. & \\
\hline
\end{tabular}

Source: Processed Data

Based on the output results above, it can be seen that the Asimp.Sig ( 2 - tailed) is 0.200 . Since Asimp.Sig ( 2 - tailed $)>$ level of significance $(\alpha=0.05$ ) or $0.200>0.05$, the regression model accepted is normally distributed. Thus, the assumptions or normality requirements in the regression model have been met. 


\section{Multicollinearity Test}

Table 8

Test Results of Multicollinearity

\begin{tabular}{|c|c|c|c|c|c|c|c|c|}
\hline \multicolumn{9}{|c|}{ Coefficients $^{a}$} \\
\hline & \multirow[t]{2}{*}{ Model } & \multicolumn{2}{|c|}{$\begin{array}{c}\text { Unstandardized } \\
\text { Coefficients }\end{array}$} & \multirow{2}{*}{$\begin{array}{c}\text { Standardized } \\
\text { Coefficients } \\
\text { Beta } \\
\end{array}$} & \multirow[t]{2}{*}{$\mathbf{t}$} & \multirow[t]{2}{*}{ Sig. } & \multicolumn{2}{|c|}{ Collinearity Statistics } \\
\hline & & B & Std. Error & & & & Tolerance & VIF \\
\hline \multirow[t]{4}{*}{1} & (Constant) & 39.412 & 5.424 & & 7.266 & .000 & & \\
\hline & 1 & .306 & .097 & .298 & 3.152 & .002 & .638 & 1.566 \\
\hline & LS & .349 & .136 & .276 & 2.566 & .012 & .493 & 2.030 \\
\hline & SE & .369 & .141 & .241 & 2.607 & .011 & .667 & 1.500 \\
\hline
\end{tabular}

a. Dependent Variable: $C B$

Source: Processed Data

The output results above prove that the tolerance value for all independent variables (I: 0.638; LS: 0.493; SE: 0.667 ) is greater than 0.1 . For the VIF value, all independent variables have a VIF value of less than 10, namely I: 1.566; LS: 2,030; SE: 1,500 . Thus it can be concluded that the independent variables operated in this study do not show any multicollinearity symptoms.

\section{Heteroscedasticity Test}

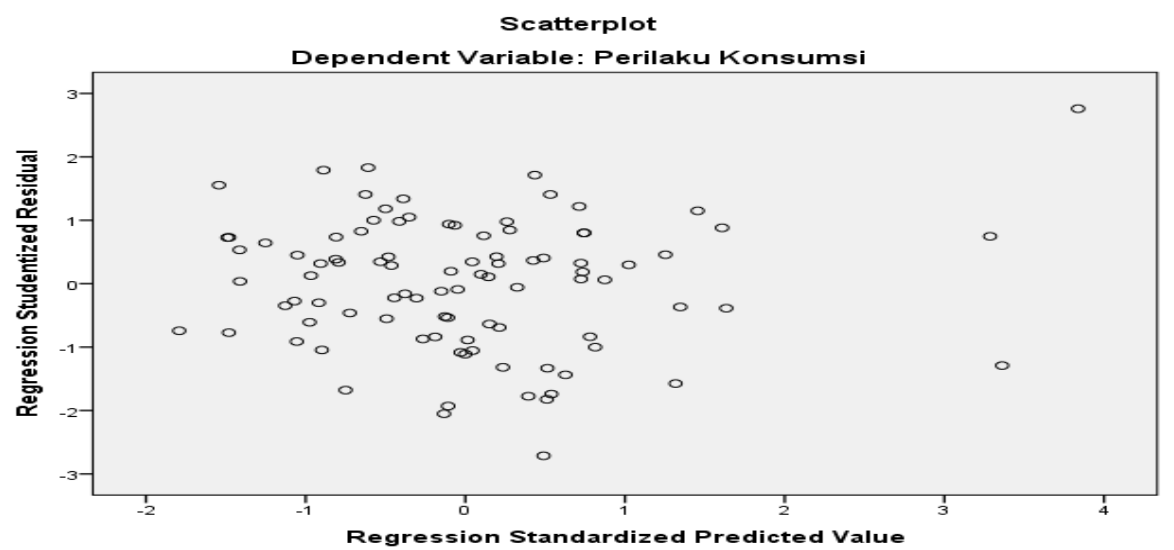

Figure 1. Test Results of Heteroscedasticity

Source: Processed Data

Based on the heteroscedasticity test results, it can be observed that the data points spread above and below or around the number of 0 , the dots do not collect only above and below, the distribution of data points does not form a wavy pattern widened 
then narrowed and widen again, and the distribution of data points is not patterned. Thus it can be concluded that the regression model used in the study is free from heteroscedasticity cases.

Table 9 Moderated Regression Analysis (MRA) Test

\begin{tabular}{|c|c|c|c|c|c|}
\hline \multirow[t]{2}{*}{ Model } & \multicolumn{2}{|c|}{ Unstandardized Coefficients } & \multirow{2}{*}{$\begin{array}{c}\begin{array}{c}\text { Standardized } \\
\text { Coefficients }\end{array} \\
\text { Beta } \\
\end{array}$} & \multirow[t]{2}{*}{$\mathbf{t}$} & \multirow[t]{2}{*}{ Sig. } \\
\hline & $\mathrm{B}$ & Std. Error & & & \\
\hline (Constant) & 39.412 & 5.424 & & 7.266 & .000 \\
\hline 1 & .306 & .097 & .298 & 3.152 & .002 \\
\hline LS & .349 & .136 & .276 & 2.566 & .012 \\
\hline SE & .369 & .141 & .241 & 2.607 & .011 \\
\hline (Constant) & 21.050 & 10.160 & & 2.072 & .041 \\
\hline 1 & .240 & .100 & .234 & 2.390 & .019 \\
\hline LS & .487 & .149 & .385 & 3.277 & .001 \\
\hline SE & .298 & .143 & .195 & 2.082 & .040 \\
\hline $\mathrm{R}$ & .183 & .086 & .176 & 2.123 & .036 \\
\hline (Constant) & 116.805 & 71.856 & & 1.626 & .107 \\
\hline 1 & -.507 & .733 & -.494 & -.692 & .490 \\
\hline LS & 1.658 & 1.373 & 1.312 & 1.208 & .230 \\
\hline SE & -2.511 & 1.940 & -1.642 & -1.294 & .199 \\
\hline $\mathrm{R}$ & -.618 & .599 & -.593 & -1.032 & .305 \\
\hline IR & .006 & .006 & .832 & 1.000 & .320 \\
\hline LSR & -.010 & .012 & -.927 & -.867 & .388 \\
\hline SER & .023 & .016 & 1.999 & 1.451 & .150 \\
\hline
\end{tabular}

a. Dependent Variable: $\mathrm{CB}$

Source: Processed Data

By looking at the value of Standardized Coefficients beta on each variable, the structural equation for the Moderated Regression Analysis is:

a. Model I

$\mathrm{CB}=\alpha+\beta 11+\beta 2 \mathrm{LS}+\beta 3 \mathrm{SE}+\varepsilon$

$=39,412+0,306$ income $+0,349$ lifestyle $+0,369$ social environment +5.424

b. Model II

$C B=\alpha+\beta 1 I+\beta 2 L S+\beta 3 S E+\beta 4 R+\varepsilon$,

$C B=21,050+0,240$ income $+0,487$ lifestyle $+0,298$ social environment $+0,183$ religiosity

$+10,160$

c. Model III

$C B=\alpha+\beta 1 I+\beta 2 L S+\beta 3 S E+\beta 4 R+\beta 5 I R+\beta 6 L S R+\beta 7 S E R+\varepsilon$

$C B=116,805-0,507$ income $+1,658$ lifestyle- 2,511social environment-0,618religiosity +

0,006 income* religiosity- 0,010lifestyle* religiosity+ 0,023social environment*religiosity+ 71,856 


\section{Determination Coefficient Test $\left(\mathbf{R}^{2}\right)$}

Table 10

Determination Result $\left(\mathrm{R}^{2}\right)$

Model Summary

\begin{tabular}{crrrr}
\hline Model & R & R Square & $\begin{array}{c}\text { Adjusted R } \\
\text { Square }\end{array}$ & $\begin{array}{c}\text { Std. Error of the } \\
\text { Estimate }\end{array}$ \\
\hline 1 & $.672^{\mathrm{a}}$ & .452 & .435 & 8.11040 \\
2 & $.691^{\mathrm{b}}$ & .477 & .455 & 7.96627 \\
3 & $.701^{\mathrm{c}}$ & .491 & .453 & 7.98178 \\
\hline
\end{tabular}

a. Predictors: (Constant), SE, I, LS

b. Predictors: (Constant), SE, I, LS, R

c. Predictors: (Constant), SE, I, LS, R, IR, LSR, SER

Source: Processed Data

The first research model indicates that the percentage of the independent variable influence on the dependent variable is $45.2 \%$. At the same time, the remaining $54.8 \%$ is explained by other variables not included in this study. The second research model proves that the percentage of the independent variable influence on the dependent variable and the moderating variable is $47.7 \%$. At the same time, the remaining $52.3 \%$ is explained by other variables not included in this study. With the moderating variable, the model is considered better for an increase from 0.452 or $45.2 \%$ to 0.477 or $47.7 \%$. Furthermore, the third research model informs us that the percentage of the independent variable interaction with the moderating variable influence on the dependent variable is $49.1 \%$. While the remaining $50.9 \%$ is explained by other variables not included in this study.

\section{Hypothesis Testing (Test T)}

Table 10

Result of Test $t$

Coefficients $^{\text {a }}$

\begin{tabular}{cccccc} 
Model & $\begin{array}{c}\text { Unstandardized Coefficients } \\
\text { B }\end{array}$ & $\begin{array}{c}\text { Standardized } \\
\text { Coefficients }\end{array}$ \\
\hline (Constant) & 39.412 & 5.424 & Beta & $\mathbf{t}$ & Sig. \\
I & .306 & .097 & .298 & 7.266 & .000 \\
LS & .349 & .136 & .276 & 2.152 & .002 \\
SE & .369 & .141 & .241 & 2.607 & .012 \\
$:$ (Constant) & 21.050 & 10.160 & & 2.072 & .041 \\
I & .240 & .100 & .234 & 2.390 & .019 \\
LS & .487 & .149 & .385 & 3.277 & .001 \\
SE & .298 & .143 & .195 & 2.082 & .040 \\
R & .183 & .086 & .176 & 2.123 & .036 \\
\hline
\end{tabular}

Published by University of Airlangga.

This is an open access article under the CC BY license (https://creativecommons.org/licenses/by-nc-sa/4.0/) 
Jurnal Ekonomi dan Bisnis Islam, Vol. 6, No. 2, July - December 2020

\begin{tabular}{cccccc}
\hline (Constant) & 116.805 & 71.856 & & 1.626 & .107 \\
I & -.507 & .733 & -.494 & -.692 & .490 \\
LS & 1.658 & 1.373 & 1.312 & 1.208 & .230 \\
SE & -2.511 & 1.940 & -1.642 & -1.294 & .199 \\
R & -.618 & .599 & -.593 & -1.032 & .305 \\
IR & .006 & .006 & .832 & 1.000 & .320 \\
LSR & -.010 & .012 & -.927 & -.867 & .388 \\
SER & .023 & .016 & 1.999 & 1.451 & .150
\end{tabular}

Source: Processed Data

a. Dependent Variable: $\mathrm{CB}$

Based on the table above, for the first model, the independent variables (income, lifestyle, and social environment) have a significant effect on the dependent variable (consumption behavior). For the second model, the independent variables (income, lifestyle, and social environment) have a significant effect on the dependent variable (consumption behavior), and religiosity has a significant impact on consumptive consumption behavior. For the third model, the independent variables (income, lifestyle, and social environment) do not affect the dependent variable (consumption behavior), and religiosity does not significantly affect consumption behavior.

\section{Test F}

Table 11

Result of Test $F$

\begin{tabular}{|c|c|c|c|c|c|c|}
\hline \multicolumn{7}{|c|}{ ANOVA $^{a}$} \\
\hline & Model & $\begin{array}{l}\text { Sum of } \\
\text { Squares }\end{array}$ & $\mathrm{df}$ & Mean Square & $\mathrm{F}$ & Sig. \\
\hline \multirow[t]{3}{*}{1} & Regression & 5209.296 & 3 & 1736.432 & 26.398 & $.000^{\mathrm{b}}$ \\
\hline & Residual & 6314.744 & 96 & 65.779 & & \\
\hline & Total & 11524.040 & 99 & & & \\
\hline \multirow[t]{3}{*}{2} & Regression & 5495.202 & 4 & 1373.800 & 21.648 & $.000^{c}$ \\
\hline & Residual & 6028.838 & 95 & 63.461 & & \\
\hline & Total & 11524.040 & 99 & & & \\
\hline \multirow[t]{4}{*}{3} & Regression & 5662.836 & 7 & 808.977 & 12.698 & $.000^{\mathrm{d}}$ \\
\hline & Residual & 5861.204 & 92 & 63.709 & & \\
\hline & Total & 11524.040 & 99 & & & \\
\hline & \multicolumn{6}{|c|}{ a. Dependent Variable: CB } \\
\hline
\end{tabular}

Source: Processed Data

From the results above, it can be concluded that in the first model, income, lifestyle, and social environment simultaneously have a significant and positive influence on consumption behavior. In the second model, income, lifestyle, social environment, and religiosity simultaneously have a significant and positive influence on consumption 
behavior. Furthermore, in the third model, namely income, lifestyle, social environment, religiosity, income * religiosity, lifestyle * religiosity, and social environment * religiosity simultaneously has a significant and positive influence on consumption behavior.

\section{The Effect of Income on Consumption Behavior}

The study results indicate that income has a significant effect on consumption behavior. A significance value obtained is $0.001<0.05$, and $t$ count is greater than $t$ table (3.152 > 1.985). The beta value of 0.298 or $29.8 \%$ indicates that income affects consumption behavior by $29.8 \%$.

The higher the income level of a person, the higher the consumption behavior and the more demand in getting excellent quality. Conversely, the lower a person's income level, the lower his consumption behavior level. It is because of low-income consumersrarely consume much. After all, their purchasing power is also low. Some Bidikmisi students spend their income to fulfill a lifestyle that is consumptive. This research is in line with a study conducted by Muhammad Reza Hermanto, proving that income has a significant relationship and influence on the consumption of a Muslim, as income and wealth are the main determining factors in consumption (Hermanto, 2015). Financial is related with consumption behavior.

\section{The Effect of Lifestyle on Consumption Behavior}

Individual's luxurious lifestyle will increase his consumptive behavior. Conversely, if a person's lifestyle decreases, his level of consumptive behavior will also decrease. A luxurious lifestyle will make students need luxury goods and services. This situation can cause students not to think about the priority scale of their needs. here, their idealism is urged so that their lifestyle avoids luxury and indulgence. When their lifestyle is good, which is not hedonic, their consumption behavior will be more rational. The study results are supported by previous research conducted by Cancer, which explains that lifestyle has a positive and significant influence on consumptive behavior (Kanserina., 2015). Furthermore, Astutistates that lifestyle has a positive effect on the consumption behavior of IKIP PGRI Bojonegoro students(Astuti, 2016).

\section{The Influence of the Social Environment on Consumption Behavior}

The study results indicate that the social environment has a significant effect on consumption behavior. Significance value obtained is $0.011<0.05$, and $t$ count is greater than $t$ table (2.607> 1.985$)$. The beta value of 0.241 or $24.1 \%$ indicates that the social environment influences consumption behavior by $24.1 \%$. 
This result follows Assael's theory of consumer behavior in NuritaDewi's research, which explains that environmental factors influence consumers in making consumer behavior purchasing decisions since the surrounding environment influences consumer choices for goods and services (Dewi et al., 2017). The study results are in line with research projects conducted by Subagio, which indicate that there is a significant influence between the social environments on student consumptive behavior (Subagio, 2019). Furthermore, Budanti et al., states that there is a significant influence between the social environment and lifestyle on the consumption behavior of students in the Economic Education Study Program FKIP UNS with a coefficient of determination (adjusted $\mathrm{R}^{2}$ ) of 0.095. It means that the social environment and lifestyle influenced student consumption behavior by $9.5 \%$, while other factors influence the remaining by $90.5 \%$ (Budanti et al., 2017).

\section{The Influence of Income, Lifestyle, and Social Environment on Consumption Behavior}

This study indicates that income, lifestyle, and social environment together have a significant effect on consumption behavior. A significance value obtained is $0.000<0.05$, and Fcount is greater than Ftable (26.398> 2.47).

This result means that the higher the value of income, lifestyle, and social environment, the higher the consumption behavior of Bidikmisi scholarship recipients. Likewise, the lower the amount of income, lifestyle, and social environment, the lower the consumption behavior. Bidikmisi students should make the campus a place to seek knowledge, instead of a place to compete to show what they have. So that the primary needs as a student are forgotten, and they will do all kinds of ways to fulfill these desires.

\section{The Effect of Religiosity on Consumption Behavior}

Based on the t-test results in the second model, religiosity partially has a significant and positive effect on consumption behavior. Significance value obtained is $0.036<0.05$, and the $t$ count is greater than the table (2.123>1.985).

This result is in line with research conducted by Desilsnaini, which states that one's religiosity will influence economic behaviors, one of which is consumer behavior (Isnaini, 2020). Students with Islamic religiosity have Islamic consumption behavior patterns in choosing halal and nutritious food (Putriani, 2015). A high level of religiosity makes Muslim consumers follow the Islamic principles of Consumption Behavior(Bukhari, 2018).

Religiosity has a positive effect on consumption behaviour, where the higher the level of religiosity, the lower the level of student's consumerism. Religiosity is full of values and norms, so religion makes its adherents to live their lives following the norms and values regulated in their religion (Syafira, 2020). Increasing individual religiosity is an effort 
to separate an individual from consumerism or excessive consumption behavior. By instilling the value that mubazir behavior is an act commensurate with the devil, it is expected that religious values can minimize a person's consumptive behavior.

\section{The Influence of Income, Lifestyle, and Social Environment on Consumption Behavior with Religiosity as a Moderation Variable}

Based on the t-test results in the third model, income, lifestyle, and social environment do not have a partial effect on consumption behavior, and religiosity does not have a partial effect on consumption behavior. This proves that religiosity (Z) does not strengthen income (X1), lifestyle (X2), and social environment (X2) on consumption behavior $(\mathrm{Y})$. The study results are in line with Herlina's, where the higher the level of religiosity (religious understanding and its application), the lower the level of consumerism (buying behavior that considers luxury goods as a measure of happiness). The $t$ value which proves this result is negative (Yustati, 2015). Bidikmisi students at UIN SU as Muslim students who study Islam, know that knowledge is an important part, and knowledge about good consuming behavior which is following Islamic teachings. As students who are instilled in religious teachings, it is expected that they will distinguish between needs and desires since those two are two different things.

\section{CONCLUSION}

The results of data analysis in this study indicate that partially, income, lifestyle, and social environment have a positive and significant effect on student consumption behavior. Income, lifestyle, and social environment simultaneously have a positive and significant impact on student's consumption behavior. Consumption behavior can become negative if unconsciously consumerism has become a culture and social disease. It has the potential to create an individualistic and materialistic society, even leading to hedonism. This phenomenon is demonstrated by the existence of a group of people who actively consume luxury products as prestige and honor as a mere fulfillment of desire. Income, lifestyle, and social environment have a positive effect on student's consumption behavior with a moderate level of religiosity. In addition, religiosity affects consumption behavior, so it can be concluded that religious knowledge or ideology can influence consumers in choosing goods to consume, based on the value they believe in. 


\section{REFERENCES}

Anggraini, R. T., Fauzan, \&, \& Santhoso, H. (2017). Hubungan antara Gaya Hidup Hedonis dengan Perilaku Konsumtif pada Remaja. Gadjah Mada Journal of Psychology, 3(3), 131-140. https://doi.org/DOI: 10.22146/gamajop.44104

Ardyanti, N. (2018). Determinants of Consumption Behavior Among Students. Dinamika Pendidikan, 13(1), 30-41. https://doi.org/DOI: https://doi.org/10.15294/dp.v13i1.15112

Arifin, B., Sulistyarini, \& Syahrudin, H. (2013). Penggunaan Beasiswa Bidik Misi pada Mahasiswa FKIP UNTAN. Jurnal Pendidikan Dan Pembelajaran, 2(12).

Astuti, R. P. F. (2016). Pengaruh Status Sosial Ekonomi Orang Tua, Literasi Ekonomi Dan Life Style Terhadap Perilaku Konsumsi. Jurnal Edutama, 3(2), 49-58. https://doi.org/http://dx.doi.org/10.30734/jpe.v3i2.36

Baining, M. E., \& Ekawati. (2018). Pengaruh Pendapatan Terhadap Perilaku Konsumtif Mahasiswa Penerima Beasiswa Bidikmisi Di Kota Jambi. Jurnal Ekonomi Syari'ah, 6(1), 89-111. https://doi.org/10.15575/syh.v6i1.197

Budanti, H. S., Indriayu, M., \& Sabandi, M. (2017). Pengaruh lingkungan sosial dan gaya hidup terhadap perilaku konsumsi mahasiswa program studi pendidikan ekonomi FKIP UNS. Jurnal Pendidikan Bisnis Dan Ekonomi, 3(2), 1-14. https://doi.org/https://doi.org/10.20961/bise.v3i2.16446

Bukhari, S. F. . (2018). Is religiosity an important consideration in Muslim consumer behavior: Exploratory study in the context of western imported food in Pakistan. Journal of Islamic Marketing, 10(4), 1288-1307. https://doi.org/doi.org/10.1108/JIMA-01-2018-0006

Dewi, N., Rusdarti, \& Sunarto. (2017). Pengaruh Lingkungan Keluarga, Teman Sebaya, Pengendalian Diri Dan Literasi Keuangan Terhadap Perilaku Konsumtif Mahasiswa. Journal of Economic Education, 6(1), 29-35.

Fauzi, F. (2020). The Effect Of Tourism Image, Service Quality, And Promotion On Religious Tourism Interest In Pringsewu Regency. Jurnal Ekonomi Dan Bisnis Islam (JEBIS), 6(1), 78-97. https://doi.org/http://dx.doi.org/10.20473/jebis.v6i1.18713

Handa, M. (2013). Gender As A Moderator Of The Relationship Between Materialism And Fashion Clothing Involvement Among Indian Youth. International Journal of Consumer Studies, 37(1), 112-120. https://doi.org/doi: 10.1111/j.14706431.2011.01057.x

Haryani, I. (2015). Hubungan Konformitas dan Kontrol Diri Dengan Perilaku Konsumtif Terhadap Produk Kosmetik pada Mahasiswi. Jurnal Psikologi, 11(1), 1-11. https://doi.org/DOI: http://dx.doi.org/10.24014/jp.v11i1.1555

Hermanto, M. R. (2015). Pengembangan Teori Keyness Dalam Jumlah Konsumsi Muslim. Signifikan: Jurnal Ilmu Ekonomi, 4(2). https://doi.org/10.15408/sjie.v4i2.2304

Hidayati, I. (2020). Peran Kontrol Diri dan Mediasi Orang Tua terhadap Perilaku Penggunaan Internet Secara Berlebihan. Gadjah Mada Journal Of Psychology, 6(1), 43-55. https://doi.org/DOI: 10.22146/gamajop.52744

Indrianawati, E., \& Soesatyo, Y. (2017). Pengaruh Tingkat Pendapatan Dan Pengetahuan Ekonomi Terhadap Tingkat Konsumsi Mahasiswa Program Pascasarjana Universitas Negeri Surabaya. Jurnal Ekonomi Pendidikan Dan Kewirausahaan, 3(2), 
214.

Isnaini, D. (2020). Relevansi Religiusitas Dengan Perilaku Konsumsi. Al-Intaj : Jurnal Ekonomi Dan Perbankan Syariah, 6(1), 111. https://doi.org/10.29300/aij.v6i1.2860

Kanserina, D., Haris, I. A., \& Nuridja, I. M. (2015). Pengaruh Literasi Ekonomi dan Gaya Hidup terhadap Perilaku Konsumtif Mahasiswa Jurusan Pendidikan Ekonomi Universitas Pendidikan Ganesha Tahun 2015. Jurnal Pendidikan Ekonomi UNDIKSHA, 5(1), 1-11. https://doi.org/DOI: http://dx.doi.org/10.23887/jjpe.v5i1.5213

Khairat, M. (2018). Hubungan Gaya Hidup Hedonis Dengan Perilaku Konsumtif Pada Mahasiswi. Jurnal Al-Qalb, 10(2), 130-139. https://doi.org/https://doi.org/10.15548/alqalb.v9i2.861

Lutfia, D. (2020). Hubungan Materialisme dengan Subjective Well-Being yang Dimoderasi oleh Religiositas pada Ibu Rumah Tangga. Gadjah Mada Journal Of Psychology, 6(1), 67-79. https://doi.org/DOI: 10.22146/gamajop.53049

Putriani, Y. H., \& Shofawati, A. (2015). Pola Perilaku Konsumsi Islami Mahasiswa Muslim Fakultas Ekonomi dan Bisnis Universitas Airlangga Ditinjau Dari TIngkat Religiusitas. Jurnal Ekonomi Syariah Teori Dan Terapan, 2(7), 570. https://doi.org/10.20473/vol2iss20157pp570-582

Rahman, F. (2020). Peran Kecerdasan Emosi Terhadap School Well-Being Siswa Smp Di Kota Yogyakarta. Al-Qalb, 11(1), 1-7. https://doi.org/DOI: https://doi.org/10.15548/alqalb.v11i1.1208

Rakrachakarn, V. (2015). Materialism And Life Satisfaction: The Role Of Religion. Journal of Religion and Health, 54(2), 413-426. https://doi.org/doi: 10.1007/s10943-0139794-y

Ratna, I. (2015). Pengaruh Tingkat Pendapatan Dan Tingkat Pendidikan Terhadap Perilaku Konsumtif Wanita Karir Di Lingkungan Pemerintah Provinsi Riau. Marwah, XIV(2), 199-224. https://doi.org/DOI: http://dx.doi.org/10.24014/marwah.v14i2.2627

Sheldon, K. (2014). Service Job Lawyers Are Happier Than Money Job Lawyers, Despite Their Lower Income. The Journal of Positive Psychology, 9(3), 219-226. https://doi.org/doi: 10.1080/17439760.2014.888583

Sirgy, M. J. (2013). In Materialisme All Bad? Effect On Satisfaction With Material Life, Life Satisfaction, And Economic Motivation. Social Indicator Research, 110(1), 349-366. https://doi.org/doi: 10.1007/s11205-011-9934-2.

Subagio. (2019). Pengaruh Lingkungan Sosial Terhadap Perilaku Konsumtif Mahasiswa Fakultas Pendidikan Olahraga Dan Kesehatan (Fpok) Ikip Mataram. Mandalanursa, 3(3), 209-222. https://doi.org/DOI: http://dx.doi.org/10.36312/jisip.v3i3.935

Sugiyono. (2017). Metode Penelitian Bisnis: Pendekatan Kuantitatif Kualitatif, Kombinasi, dan R\&D. Alfabeta.

Suminar, E. (2015). Konsep Diri, Konformitas dan Perilaku Konsumtif pada Remaja. Jurnal Psikologi Indonesia, 4(2), 145-152. https://doi.org/DOI: https://doi.org/10.30996/persona.v4i02.556

Syafira, F. N. (2020). The Effect Of Religiosity And Trust On Intention To Pay In Ziswaf 
Collection Through Digital Payments. Jurnal Ekonomi Dan Bisnis Islam (JEBIS), 6(1), 98-115. https://doi.org/http://dx.doi.org/10.20473/jebis.v6i1.17293

Universitas Islam Negeri Sumatera Utara. (2015). Standard Operating Procedure (SOP) Management of Poor Achievement Education (Bidikmisi) State Islamic University of North Sumatra (UIN SU).

Yustati, H. (2015). Konsumsi dalam Perspektif Ekonomi Islam (Regresi Religiusitas terhadap Konsumerisme pada Mahasiswa UIN Syarif Hidayatullah Jakarta). Jurnal Indo-Islamika, 5(1), 25-50. https://doi.org/10.15408/idi.v5i1.14786 